\title{
Religion and the limits of individualisation in ancient Athens: Andocides, Socrates, and the fair-breasted Phryne
}

In a recent path-breaking study of the individual in the religions of the Ancient Mediterranean, classical Greece was almost entirely absent, except for a single contribution on the mystery cults (Waldner 2013). Does this mean that these cults were the only possible areas for the expression of individual ideas and practices in Greek religion? Does the stress on agency and communication in ancient religion help us to discover or recover the process of individualisation or individuality in ancient religion (Rüpke 2015, 2016)? Or should we, rather, pursue a different approach and a different term, such as 'personal religion' (Kindt 2015)? Ancient Greece has been a stepchild in previous discussions examining religious individualisation from a historical perspective. Yet Athens, in particular, offers various possibilities for an analysis of the problem of individual choices and their historical locations. The latter is important, as it is only through a comparison of the various historical circumstances that we can acquire a better insight into processes of individualisation.

Julia Kindt $(2015,45)$ has persuasively claimed that Theophrastus' 'Superstitious Man' 'illustrates the plurality of religious voices in the ancient Greek city'. This is true. Yet her observation also implies that there evidently existed a fair amount of freedom of expression within ancient Greek religion. If we follow the reasonable assumption that all free Athenians had this freedom, what then does 'personal religion' mean exactly? Is it really the right term? And what about the gender aspect? All of Kindt's examples are of males, if I read her correctly. What neither she nor Jörg Rüpke comments upon are the limits of this personal freedom. Even if there is a spectrum of possibilities for personal agency, there must also be a limit. And this limit is established by the civic community when it accuses a person of asebeia, 'impiety'. Although I agree with recent criticisms of the degree of importance attached to polis religion (Bremmer 2010; Rüpke 2011; Versnel 2011, 88-142; Kindt 2012), it remains a fact that the male members of the polis eventually determined what was allowed in religion and what not - even if messy margins arose from the process of establishing the limits of religious individuality. Of course, influential individuals were usually members of the higher classes and poorer and dependent persons probably had far fewer possibilities for developing their individuality, constrained as they were by poverty or slavery. Yet we should not deny them individuality either (Thomas 2010, 43). 
Even when we accept that Athenians in classical times had a fair amount of religious leeway, there were also people who went too far and who provoked a negative reaction from their fellow citizens. These are the people in whom I am interested in this contribution, as they offer us a lens into personal religious motivations and convictions, a perspective that is almost non-existent in the case of most Athenians. As Arnaldo Momigliano (1987, 197) once observed, 'we know little of how an individual behaved during his life in relation to the religious community to which he belonged'. Many Athenians may have made personal choices in matters of religion, but the outcome was not interesting or challenging enough to leave any traces in our evidence. This is different in those cases in which our sources report impiety trials. It is for this reason that these cases form the subject of my contribution to this publication.

Unfortunately, Athenian law is no easy matter to deal with and is, appropriately, the domain of true specialists. We do not have a detailed code civil or pénal to enlighten us as to what was permitted and what was unlawful in ancient Athens. Yet some qualities of that law are clear. The law stated the offence together with procedural consequences and the sentence. However, it fell to the members of the jury to decide whether the accusations brought before them really fitted the category of the offence, such as treason or impiety. This procedure left a free playing field for both the accusers and defenders of the defendant to make their cases in front of a jury of 501 male Athenians over thirty years old, all good men and true.

In my contribution, I will look at three well-known cases in which impiety played a role: the detail-rich trial of Andocides $(\S 1)$, the famous trial of Socrates (§ 2), and the salacious trial of the courtesan Phryne $(\S 3) .{ }^{1}$ In all these cases, we have some information about the trial but never all the evidence that was once available to the jurors. In the case of Andocides, I discuss his trial in detail to give an idea of what was at stake in a trial for impiety and what arguments the prosecution could produce. Having looked at the trial, we then focus on its background in connection with the theme of individualisation. For the trial of Socrates, we will concentrate on the grounds for the prosecution and condemnation, and for that of Phryne we will try to reconstruct what this famous courtesan actually did in order to be brought to justice. In the conclusion (§ 4) we will tie these cases closer to the subject of religion and individualisation.

1 For a very full discussion of all Athenian impiety trials, see Filonik 2013 and, from a more narrative perspective, Filonik 2016. 


\section{The case against Andocides}

Usually, when studying trials in classical Athens, we are confronted with a dearth of sources. Rarely do we get a view from both the defence and the prosecution: it is only in the cases of Demosthenes and Aeschines that we have two speeches from the same trial that can both be relied upon, viz. in the Embassy trial of 343 $\mathrm{BC}$ and the Crown trial of $330 \mathrm{BC}$. The prehistory of a case usually has to be reconstructed from the internal evidence of one speech, and often the outcome of the trial remains uncertain, unless it is particularly famous, as in the case of Socrates (see below, § 2). This makes the case we start with all the more interesting, as we do have quite a bit of information about the preceding events, which were nothing less than spectacular. Our main focus will be Lysias 6, a speech for the prosecution of Andocides, one of the great Athenian orators. It was probably in the autumn of $400 \mathrm{BC}$ that our trial took place, but its roots go back to $415 \mathrm{BC}$ (Furley 1996, not always persuasive).

In the summer of that fateful year, the Athenians went off to conquer Sicily with their fleet. The failure of the expedition was the beginning of the end for Athenian hegemony, both politically and, it might be argued, culturally. Yet before the fleet had even set sail, the city was rocked by two great scandals: the profanation of the Eleusinian Mysteries and, only shortly before the date of departure, the mutilation of the herms (most recently, Murray 1990; Graf 2000; Todd 2004; Hornblower 2008, 367-72; Osborne 2010, 341-67 [the herms]; Rubel 2000, 2014). Andocides was implicated in both scandals and had to leave the city, although he escaped execution by turning informer. When he finally managed to return after the political amnesty of $403 \mathrm{BC}$, he was indicted for having transgressed a decree by a certain Isotimides that barred people guilty of impiety from the Agora and the sanctuaries. Andocides was accused of having entered the Eleusinian sanctuary of Demeter and Kore, in violation of this decree. Moreover, some days before the trial, he was additionally accused of having put a suppliant-branch on the altar of the two goddesses, which was forbidden during the time of the performance of the Mysteries, from September the 19th to the 22nd, which gives us the terminus post quem after which the trial must have soon taken place. We also have the speech in which Andocides defended himself. However, for our present purposes we will concentrate on the speech of the prosecution, although with half an eye on Andocides' defence.

The speech is not without problems. For the present, we can agree with the conclusion of Stephen Todd after a detailed discussion of all the various suspicious aspects of the speech: 'what we have is in origin and in essence a genuine speech delivered at the trial', with probably a few post-trial revisions and 
additions. ${ }^{2}$ Moreover, the speech is not complete and seems to have been considerably longer than what we have now (Todd 2007, 408). The speaker of the speech is not mentioned by name, but there are strong arguments that he was Meletos, one of the accusers of Socrates (Martin 2007, 149-51; Todd 2007, 408-11). As said, we also have the defence speech by Andocides himself and it is clear from his later political career that he won the case; had he lost he would almost certainly have been executed for his impiety.

So, let us now turn to the speech of the prosecution, which starts with an example of impiety. A man gave a horse to a temple, presumably that of Eleusis, but stole it back afterwards. Consequently, he was no longer able to eat and perished from hunger (Lysias 6.1). The prosecutor mentions this event as a story told by the hierophant, the most important priest of the Eleusinian Mysteries. It is unclear from the speech whether it is the currently officiating priest or an earlier one but this detail is unimportant. We are, presumably at the beginning of the speech, already confronted with the grave consequences of a transgression against one of the most holy cults of Athens: the Eleusinian cult of Demeter and Kore. Evidently, sinning against these goddesses was a certain invitation to the most terrible of consequences (Bremmer 2019). It is a fairly natural transition from this anecdote to the speaker suggesting that if Andocides emerges as a free man from his trial he could be elected Basileus, the leading civic official at the Mysteries, who was responsible for ensuring that no impious acts were performed during the Mysteries (4). What impression would that make on those coming to be initiated or simply to have a good time at the fair of the Mysteries (5)?

In fact, it would be impossible both to stick to the ancestral customs and to retain Andocides, the prosecutor continues, and he mentions that only shortly after his return from exile Andocides had charged a certain Archippos with impiety, nota bene, against his own ancestral herm, presumably the one in front of his house (11). This was a rather audacious charge given that Andocides himself was implicated in the scandal of the mutilation of the herms in 415 . The fact that Archippos could escape the charge by paying some kind of fine (12) seems to suggest a certain amount of guilt but also that there was no appetite for repeating the prosecution of $415 \mathrm{BC}$ when a considerable number of people were executed and/or their goods confiscated.

Subsequently, the prosecutor mentions various objections that could be raised against a condemnation (13-15). Yet if the Athenians ban people from cities in which they have wounded or mutilated others, and execute them should they

2 Todd 2007, 407 (quotation). For my translations, I follow Todd, whose commentary has also been very helpful. 
return to those cities, how can they let Andocides return to the sanctuaries of the gods whose statues he had mutilated? The objection (15) does not seem to be very strong since Andocides did not enter a sanctuary of Hermes, whose statue he was supposed to have mutilated; in fact, sanctuaries of Hermes did not even exist in Athens (Versnel 2011, 350f.) but strict logic cannot be expected here. And if other cities excluded people from their sanctuaries because of impiety committed in Athens, why should not the Athenians themselves be more careful in this respect (16)? The more so as Andocides is even more impious than the 'atheist' Diagoras, who committed words of impiety against rites and festivals not of his own city, whereas the former committed those acts against his own city (17) - an interesting 'local' view of Greek religion. Andocides was even so impious as to become a ship-owner who expected to be safe at sea (19), an argument brilliantly used and turned to his own advantage by Andocides in his defence speech (Andocides 1.137-39). The prosecutor concludes this part of his speech by noting that gods do not always punish instantaneously like humans but often let their children pay the price for the crimes of their ancestors (Gagné 2013), if they do not die prematurely themselves (20). In other words, according to the speaker the gods punish criminals during their lives or via their children but not via a post-mortem punishment, as happened to the great mythological sinners Tantalus and Sisyphus. Our speaker may be traditional in his beliefs but he is not terribly religious.

After these 'religious' arguments our speaker, somewhat abruptly, continues with a report of Andocides' life since his release from prison for his participation in the scandal of the herms. This report, the truth of which we cannot verify, consists of a series of crimes Andocides purportedly committed when travelling from one place to the next during his exile (21-29). His constant suffering is clearly meant to be seen as a slow punishment by the gods for his impiety (32). ${ }^{3}$ Andocides even goes so far as to give advice in religious matters, such as sacrifices and processions (33) - evidently a behaviour that is supposed to make the audience's blood curdle.

The prosecutor proceeds to outline possible lines of defence to which Andocides may resort and which do not concern us here (35-49) before returning at the end to the crimes Andocides was supposed to have committed in 415 BC: 'This man put on a robe, imitating the sacred rites, and displayed them to those who were not initiates. He spoke out loud the words which must not be spoken. He mutilated those of the gods whom we worship, and to whom we sacrifice and pray, honouring them and purifying ourselves' (51). The prosecutor pulls no punches and even conflates the two scandals, the profanation of the Mysteries

3 Todd 2007, 461-62 compares Lysias, fr. 195 Thalheim. 
and the mutilation of the herms, although Andocides was only implicated in the latter scandal to some extent and strongly denied any connection with the former. In addition, and he now returns to the actual charge, Andocides had transgressed the law of Athens by sacrificing on altars he was not allowed to and even by entering the Eleusinion and washing himself in its lustral basin - something he, due to the impurities of his previous life, should not have done. By purifying the city of Andocides, the prosecutor suggests, the city would expel a scapegoat, the ritual figure whose ritual expulsion purified the city yearly, even though we cannot be sure if that ritual was still practised around 400 BC (53) (Bremmer 2008, 175-96).

The speech concludes with advice given by the son of a hierophant, that is, once again by somebody associated with the holy Mysteries of Eleusis. This man recommended to always put somebody guilty of impiety on trial so that every juror would individually have to decide what the verdict should be (54). And this is how the jurors should act with Andocides: 'He will beg and beseech you, but do not have pity. It is not those who die justly, but those who do so unjustly, who deserve your pity' (55).

There are several problems with this speech, one of which is that the religious content has sometimes been overemphasised: we lack part of the speech and in the surviving part the prosecutor focuses in particular on religion at the beginning and at the end. The missing parts may well have been filled with further accounts of supposed crimes committed by Andocides. Yet it is clear that when religion plays a role, the speaker is at pains to connect Andocides' misdeeds to the Eleusinian Mysteries, whose most important priestly genos, the Eumolpids, he mentions three times $(2,10,54)$. This is perhaps not surprising, as we know from Andocides' own speech that the jury consisted exclusively of citizens who had been initiated into the Mysteries (Andocides 1.29). Moreover, there is a focus on purity. Andocides had polluted the holy water of Eleusis, which means that everybody else using that water would be polluted. However, by being accompanied out of the city as a scapegoat he would make Athens pure again. It is not only in connection to the gods that Andocides is an impious figure but, by implication, he is also somebody who disturbs the civic cohesion (Martin 2007, 148).

The content of this speech makes much of impiety by focusing on religious matters. This should not give the impression that such a focus was normal. On the contrary. It is one of the surprising outcomes of a recent study that religion played a lesser role than we would have expected even in accusations of impiety (Martin 2007). In our case, the prosecutor stressed the role of the Eleusinian Mysteries as perhaps the most prestigious cult of the Athenians. Given that Andocides was accused of having committed an impiety by entering the Eleusinian sanctuary, one must say that the speech is fairly focused. The speaker can hardly have been the main prosecutor, who was a certain Cephisius (Andocides 1.121), 
but he will have been one of the supporting cast in the prosecution who focused on one of the aspects of the case. Another of the prosecutors, possibly even the driving force behind the accusations as Andocides claimed (Andocides 1.117-31), was Callias, so well known from Plato's dialogues. Callias belonged to the second priestly genos of Eleusis, the Kerykes, and occupied the position of Dadouchos, the second most important office in the Eleusinian Mysteries. As Andocides himself may well have also been a member of the Kerykes, there seems to be an Eleusinian subtext to the trial that escapes us (Todd 2007, 402). In the end, we cannot judge how many acts of impiety were raised against Andocides, as only this speech survives, whereas the main speech, and perhaps others, must have concentrated on other aspects of the charges. One cannot escape the impression that religion was just one of the grounds for accusation. Other speakers most likely also returned to the events of $415 \mathrm{BC}$.

When we look back at the accusations, we see that they all try to paint Andocides as negatively as possible. This vilification undoubtedly has to be connected with Andocides' implication in the mutilation of the herms scandal of 415 BC. What is interesting to us is that despite the seriousness of the impiety at issue, it was possible for an Athenian to escape condemnation. The outcome of the trial is, therefore, a very interesting testimony to the leeway Athenians had in matters of religion. If levelled at the wrong moment, a charge of impiety could be fatal, while at another more felicitous time one might escape without serious damage (see below $\S 4$ ).

At the same time, the trial of Andocides took place against the background of the biggest religious scandals Athens had ever known, even though these were already fifteen years in the past: the profanation of the Mysteries and the mutilation of the herms, both of which are referred to by the prosecutor. In the case of the profanation, the actual performance of the Eleusinian Mysteries was parodied. In the case of the herms, the faces of the statues of the god were mutilated, their phalluses lopped off and the statues themselves sometimes knocked over (Hornblower 2008, 372-75). These targets were not just chosen arbitrarily. The Mysteries were the most solemn and prestigious festival of Athens, and Hermes was the god most popular on vase paintings and the only one who was the object of real human affection (Versnel 2011, 335-43). Fritz Graf (2000, 123), followed by Simon Hornblower (2008, 371f.), plays down the identity of Hermes and herm. However, the identity of god and statue was a recurrent feature all through antiquity (Bremmer 2013; Hölscher 2017, 86-102) and vase paintings regularly show the statue of Hermes moving towards or otherwise communicating with the worshipper, the only god to do so regularly (Klöckner, in preparation). Consequently, both religious transgressions struck at the heart of Athenian religion. 
In the current discussions, religious individualisation in antiquity is mainly studied in connection with changes in religion or transformations of traditional piety. In these Athenian cases, however, we can see groups of people rejecting traditional piety. The recurring atheistic statements in Euripides' tragedies show that such views formed part of contemporary discourse (Lefkowitz 1987, 1989; Riedweg 1990a, b). Moreover, Euripides' late tragedies problematise the position of the gods: his Ion and Orestes show the protagonists Creusa and Orestes deserted by the gods, while in his Helen and Iphigeneia in Tauris gods no longer play a significant role. In Thucydides, the gods are simply absent and the religious factor is almost neglected in his work (Yunis 1988; Fusillo 1992 (with extensive bibliographies); Hornblower 2010, 25-53; Whitmarsh 2015, 97-114), just as the name of a sacrilegious club like the Kakodaimonistai, 'Worshippers of bad luck', show to what extent many in the upper classes had become estranged from traditional religion (Murray 2000).

In modern times, voluntary associations proliferated from the middle of the seventeenth century onwards, thickening the space of the social and enabling the quick communication of new ideas (Hunt 2014, 85-86). We may well see a similar process at work in antiquity, as the blasphemous acts were perpetrated by members of political clubs, upper-class and often not that old - Andocides was about 25 in $415 \mathrm{BC} .{ }^{4}$ It seems likely that the new ideas about the gods and new lifestyles, such as Orphism, ${ }^{5}$ were discussed in these clubs and thus more rapidly diffused than would otherwise have been the case.

The affairs of $415 \mathrm{BC}$, then, point to a religious climate in which many of the upper classes may have started to debate about, or even doubt, the gods, but only a few actually went so far as to make fun of them. This approach was clearly the choice of a minority but their exploration of the religious possibilities evidently went too far for most of the population. Precisely this tension also lies at the root of the most famous Athenian trial for impiety, to which we now turn.

\section{The trial of Socrates}

Around $180 \mathrm{AD}$, the pagan satirist Lucian published a blistering attack on the pagan philosopher Peregrinus, about whom he noted some interesting details concerning the latter's Christian period. As he observed, in the Christian

4 McGlew 1999; Hornblower 2008, 378 and 916-9. Note also the prominence of youths in the oligarchic revolution of 411: Thucydides 9.69.4; Xenophon, Hellenica 2.3.23.

5 Cf. Euripides, Hipp. 986-87 where Hippolytus refers to a small group of age-mates. 
congregation Peregrinus was only second after Jesus, 'whom they still worship, the man who was crucified in Palestine because he introduced that new cult into the world' (Peregrinus 11). Why would Lucian think that Jesus was killed because he had introduced a new cult? The answer is perhaps somewhat surprising. In 399 BC, the Athenians had brought Socrates to trial on the following charge of impiety, graphê asebeias: 'Socrates does wrong by not acknowledging the gods the city acknowledges, and introducing other, new powers (daimonia). He also does wrong by corrupting the young. The penalty should be death'. ${ }^{6}$ Evidently, many Athenians saw Socrates as somebody who had introduced new divinities (Parker 1996, 199-207; Rubel 2000, 342-63 = 2014, 74-98; Millett 2005; Ober 2011; Versnel 2011, 554-59; Bremmer 2017, 73). This had not escaped Justin Martyr, who noted that Socrates was condemned on the charge of 'introducing new divinities (daimonia)' and compared him to Jesus: Justin (I Apol. 5, cf. Pfättisch 1908) clearly knew the official Athenian charge. The Christians even called Peregrinus a 'new Socrates' (12), just as they occasionally compared Christian martyrs to Socrates. In fact, the Smyrnean martyr Pionius, who died under the persecution of the Emperor Decius, compared himself not only to Socrates but also to Aristides and Anaxarchus, other pagan 'saints' (Martyrium Pionii 12). By relating Jesus and their own martyrs to pagan examples of virtue, the early Christians removed them from the criminal sphere and claimed the moral high ground (Harnack 1906, 17-49, criticised by Geffcken 1908; Benz 1950/51; Döring 1979, 143-61; Dassmann 1993, 39; Baumeister 2009, 22-8). The example shows the longevity of the tradition of the trial of Socrates and what one group of people in antiquity appropriated from that trial. We notice that the Christians focused on only one part of the accusation, but at least they stuck to the original charge.

The preservation of (part of) the original charge was not a given, as becomes clear when we get much closer to the actual event. Only some fifty-five years after Socrates' execution, the orator Aeschines stated in an attack on his opponent Demosthenes: 'After all, men of Athens, you did put to death Socrates the Sophist, because he was shown to have been the teacher of Critias, one of the Thirty (Tyrants) who subverted your democracy' (Against Timarchos 173). Interestingly, nothing is mentioned here about the religious charge of introducing new gods; Aeschines refers only to Critias, who might indeed count as an example of a corrupted youth, as he was a follower of Socrates in his younger days (van der Horst 2006; Danzig 2014). And indeed, according to the Attic rhetor Polycrates

6 The original wording has been handed down by Favorinus, fr. 34 Barigazzi (apud Diogenes Laertius 2.40), tr. R. Parker; note also Xenophon, Memorabilia 1.1.1, Apology 10; Plato, Apology 24b8-c1, Eutyphron 3b; Philodemus, On Piety, 1696-97 Obbink; Servius on Vergil, Aeneid 8.187. 
(fragment 8 Sauppe), who wrote a speech for the prosecution, Socrates had been the teacher of another notorious politician, Alcibiades. Since Xenophon notes that one of the speeches for the prosecution mentioned that Socrates had been the teacher of Critias, the most notorious of the Thirty Tyrants whose rule of terror in 404/403 had been responsible for the murder of many wealthy Athenians, it seems reasonable to suppose that Aeschines draws on this same speech (Isocrates 11.5; Xenophon, Memorabilia 1.2.12). When we consider what the collective memory of Athens would have cared to remember about the trial, it seems, perhaps, less strange that they did not choose to focus on the issue of the new gods. The tyranny of the Thirty had been a traumatic experience for Athens, and its many murders and confiscations must have left a much deeper impression on the collective memory than did the charge of introducing new deities.

Although, unfortunately, much less clearly expressed than by Aeschines, the rhetor Hyperides seems to refer to the same charges when he said of the Athenians, only forty years after the trial (around $360 \mathrm{BC}$ when some of the witnesses to the trial would still have been alive), that their ancestors had punished Socrates epi logois, 'for his words', rather than for his deeds (Hyperides, fr. 59 Sauppe = fr. 65 Jensen). Evidently, in Hyperides' recounting, it had not been for something Socrates had done that he was put to death but for what he had said. These, admittedly few, words also seem to point towards Socrates' teaching rather than any undemocratic acts.

We can now see that the official charge did not play the dominant role we might expect from a modern perspective. In fact, although at an Athenian trial a person could be convicted of one crime only, the prosecution could, and often did, produce people who enlarged upon that one charge and even produced new arguments, unrelated to the charge, in order to influence the jury (Hansen 1995, 12-13). Thus Xenophon mentions also the charge that,

Socrates induces those who converse with him to scorn the laws by calling it madness to allow our magistrates to be selected by lot whereas no one would be willing to take a pilot, an architect or even a teacher of music on the same terms. But mistakes in such matters would be far less fatal than errors in what concerns the polis. In the young such arguments stir up contempt of the constitution and make them violent.

(Xenophon, Memorabilia 1.2.9, tr. Hansen)

Here we see a completely different argument altogether, viz. inducement to scorn the laws, in which the young are mentioned at the end. The vulnerable young are certainly important here but they are clearly not the exclusive object of this charge, which went much further and seemingly included all Athenians.

Socrates, on the other hand, seems to have directed his own response to the charge of 'atheism'. He first denied that he had taken any interest in natural 
philosophy, probably in order not to be associated with philosophers such as Anaxagoras, who had denied the moon its divine status and therefore had also been charged with impiety (Parker 1996, 208f.; Whitmarsh 2015, 115-24; Haake 2016). He also countered the charge of atheism by invoking his daimonion in order to prove that he believed in the gods. The latter argument can hardly have been very persuasive, given the personal character of his protective spirit (Lännstrom 2012; Brandt 2017). Finally, he pointed to his own decent behaviour during the trial of the Athenian generals who had been summarily executed in 407 and his refusal to cooperate with the Thirty (Plato, Apology 32B-D; Xenophon, Memorabilia 1.1.18).

In one of the best recent discussions, Mogens Hansen $(1995,26)$ states that 'Socrates was sentenced for not sharing the ordinary Athenian's views about the gods, and probably also for having criticised the democratic institutions'. I am not sure that this is the right way to formulate the problem, as we have very little knowledge of what the ordinary Athenian thought about the gods. When we now look back at the charge against Socrates we can see that it contained three elements: (1) not acknowledging the gods, (2) introducing new ones, and (3) the corruption of youth. Let us briefly consider the modern discussions of these three points.

First, it seems that there was indeed resentment in Athens about the manner in which some philosophers, such as Anaxagoras and Diogenes of Apollonia, talked about the gods. Yet 'in practice, no doubt, the Athenians very rarely moved against verbal impiety' (Parker 1996, 209). Secondly, it is true, as we will see shortly (below $\S 3$ ), that in the course of the fourth century people were charged with, and sometimes condemned to death for, introducing new gods. However, by $400 \mathrm{BC}$ we have a century behind us in which Athens had seen the introduction of many new cults and gods, from Bendis to Asclepius and from Adonis to Sabazius. Yet we do not have a single reliable example of anybody being executed for such an introduction (Parker 1996, 152-98 and 2011, 273-77). In fact, Socrates is the first we know of to have been charged in this way.

This leaves us with the third accusation, that Socrates corrupted the young. It is exactly this aspect of the charge that we saw mentioned in references to the trial over the following decades. From Plato's Apology (33 A-B) we can see that Plato thought it necessary for his Socrates to deny that he had been any man's teacher or that he had asked fees for his teachings, as the sophists were wont to do (Fredal 2008). Evidently, Socrates' connection with the sophists was the background for the charge of corrupting the young, as Plato also realised. The connection was already a main topic of Aristophanes' Clouds, of which a version from the early 410s has survived (Laks and Saetta Cottone 2013), but in the Birds of 414 BC Socrates is also closely associated with Laconising tendencies and his admiration for Sparta must have been well known (Dunbar 1995, 636-37; Laks and Saetta Cottone 2013). In short, Socrates was closely connected not only to 
Athens' archenemies but also to politicians such as Alcibiades and Critias who had inflicted so much misery on the city in recent decades.

In the end, we cannot be certain about the motives of the jurors but the evidence we do have points towards a preponderance of political motives rather than religious ones, ${ }^{7}$ as indeed seems to have been the case in several other Athenian trials of that time. ${ }^{8}$ Yet the religious side should not be neglected altogether. Xenophon, who was a contemporary of the trial, relates in his Apology (14.3) that a number of jurors felt phtonos, 'envy', towards Socrates in response to the special relationship with the divine that he claimed. In the end, we simply cannot be certain of the motives of the jurors, but we do note that the later Greek tradition, with the exception of Christian swriters, hardly paid any attention to the religious issue, a fact that has not been taken into account in recent discussions.

\section{The trial of Phryne}

After the trial of Socrates, the next most famous Athenian impiety trial, certainly in terms of later interest, is surely that of the famous courtesan Phryne. In modern times, sculptors (Jean-Jacques Pradier, Phryne, 1844-45, cf. Lapaire 2010, 331-33), painters, ${ }^{9}$ poets (Ryan 1993), novelists, ${ }^{10}$ detectives,${ }^{11}$ composers (Camille SaintSaëns, Phryné, 1893; Edmund Eysler, Phryne, 1906), and even a modern movie director, ${ }^{12}$ have all been inspired by her trial, although rather by the supposed climax than by the accusation of impiety levelled against her. Yet her case is a clear-cut trial for impiety and deserves to be analysed in closer detail. ${ }^{13}$

7 This seems at least clear for one of the prosecutors, Anytus, see Sato 2005-2008; Lenfant 2015. 8 Cf. Parker 1995, 202: 'It may be that an accusation of impiety was almost never brought before an Athenian court without political anxiety or hatred being in the background'; Todd 2007, 411: 'the political subtext that is common in impiety trials at Athens', cf. his commentary on Speeches 5-7 of Lysias.

9 Jean-Léon Gérôme, Phryné devant l'aréopage, 1861, cf. Vouilloux 2002; more in general, Wittenburg 2007, 210-4; Corpataux 2009; Kepetzis 2011, 301-5.

10 Nonce Casanova, Phryné: roman de la Grèce antique (Paris, ?1900, often reprinted). The name looks like a pseudonym, the more so as nothing seems to be known about the author (b. 1873).

11 The Phryne Fisher historical mysteries by Kerry Greenwood, cf. http://en.wikipedia.org/wiki/ Kerry_Greenwood (accessed 3-1-2017).

12 Mario Bonnard, Frine, cortigiana d'Oriente, 1953: http://it.wikipedia.org/wiki/Frine, cortigiana_d\%27Oriente (accessed 3-1-2017), cf. Cavallini 2008, 214-7; Schrödl 2013.

13 For Phryne and her trial, see more recently Bartolini 1977, 116-9 (with previous bibliography); Versnel 1990, 118-19 (several mistakes in his Greek quotations), 127-9; Cooper 1995; Parker 1996, 162-63, 214-17; Gherchanoc 2012; Eidinow 2016, 23-30. 
Phryne was born in Boeotian Thespiae and came to Athens as a child, probably around 370 BC, where she lived the rest of her career (all data: Raubitschek 1941). Around 347 or 338 BC, she was accused by a former lover, Euthias, ${ }^{14}$ of impiety. A summary of the charges against her have been preserved in a third-century AD anonymous rhetorical treatise, the so-called Anonymus Seguerianus, which contains the abbreviated version of an earlier treatise, of which the date is unknown. By all accounts, the source is reasonably early and, it seems, reliable. It reports: 'Phryne accused of impiety: for she held a procession in the Lykeion, introduced a new god and assembled revel bands of men and women'. The report continues with what is probably the summing up of the prosecutor: 'So I have demonstrated to you that Phryne is impious: she has led scandalous revels, is the introducer of a new god and assembled unlawful revel bands of men and women'. ${ }^{15}$

Phryne was the most beautiful courtesan of her times and many passages from ancient authors testify to the spell of her beauty (Morales 2011). It is evident that this beauty saved her in the end, but our sources are divided regarding the manner in which she achieved this result. Our oldest source, Posidippus, a comic poet of the end of the fourth century - thus not that long after the trial - mentions that: 'Though she is reputed to have done great harm to lives, she captured the court with regard to her life, and by taking the hand of the jurors one by one - a not unusual gesture in cases of supplication (Boegehold 1999, 19; Naiden 2006, 102; Pedrina 2006) - with her tears she barely saved her life' (fr. 13 Kassel-Austin). Yet around the same time, we hear of the most famous version, that is, that thinking his case lost Hyperides ripped open the dress of Phryne and showed her breasts to the jurors, who were struck by a superstitious fear that they might kill a priestess of Aphrodite (presumably because of her beauty) and let her off ${ }^{16}$; a later version even has Phryne herself ripping open her dress (Alciphron 4.4).

Now, the gesture of baring the breasts was not unknown in cases of supplication and all jurors must have been familiar with the passage of the Iliad (22.77-91) in which Hecuba bares a breast in order to persuade Hector not to confront

14 Hyperides, fr. 172, 176 Jensen; Alciphron 4.3-5; Cooper 1995, 309-10.

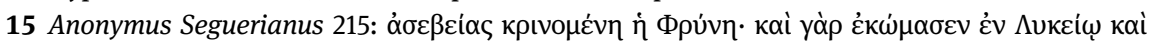

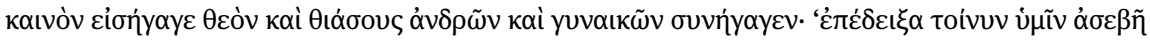

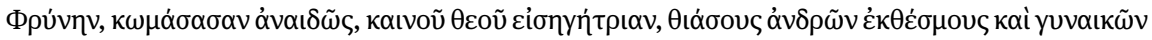

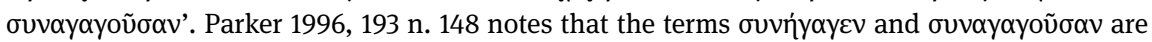
technical terms for the recruitment of temporary (Dem. 19.281; IG $\mathrm{II}^{2} 1177.4$ ) or permanent (IG II 1297.4) thiasoi, to which the case of Phryne has to be added.

16 Idomeneus of Lampsacus, FGrHist 338 F 14 = Brill New Jacoby 338 F 14A with Cooper ad loc.; Hermippus of Smyrna, FGrH 1026 F 46 with Bollansée ad loc.; Quintilian, Inst. 2.15.9; [Plutarch], $X$ orat. 849D-E; Athenaeus 13.590D-F; Sextus Empiricus, Math. 2.4. 
Achilles - a maternal gesture also attested of Clytemnaestra and Jocaste. ${ }^{17}$ Of a more sexual nature is the case of Helen, who avoided being murdered by Menelaos by showing her, undoubtedly beautiful, breasts. ${ }^{18}$ Similar cases of supplication, but also with erotic undertones, are the shedding of their dresses by the young girls Iphigeneia, Polyxena and Makaria at the very moment that they were to be sacrificed. ${ }^{19}$ In short, the supplicatory gesture of the baring of the breasts was certainly not unknown, although it is exploited here to great effect. The fact that our earliest source does not mention the baring has raised doubts about the reliability of the anecdote, but the testimony of a comic poet out of context can hardly be considered decisive. ${ }^{20}$ Given that Phryne was a courtesan, it might have been thought that her naked beauty was well known. However, it is precisely of Phryne that we are told that nobody ever saw her naked, except during her participation in the Eleusinian Mysteries and the Posidonia of Aegina. ${ }^{21}$ The unveiling of her breasts therefore, if it actually happened, must have been a truly sensational moment.

Unfortunately, the speech in her defence by Hyperides has survived only in uninformative fragments (fr. 171-180 Jensen). This is all the more regrettable as the speech was highly admired in antiquity for its grace, subtilitas, and ability to invoke pity. ${ }^{22}$ It seems that all the accusations were related to the introduction of a new god: Isodaites. We are poorly informed about this god, and recent discussions have not taken account of the fact that our main information derives from Hyperides' own speech, in which he had the greatest interest in depicting this god as bad and as insignificant as possible. The lexicographers relate the following: 'Isodaites, mentioned by Hyperides in his oration for Phryne. Some foreign daimôn for whom lower-class women, especially those of little virtue, used to practise mysteries'. ${ }^{23}$

17 Euripides, Phoen. 1567-9 (Jocaste), Electra 1206 and Orestes 526-9, 839-43 (Clytemnestra). 18 Lesches, Ilias parva, fr. 17; Euripides, Andromache 628-31; Aristophanes, Lysistrata 148-54, 155-56.

19 Iphigeneia: Aeschylus, Agamemnon 239, cf. Harder 2002, 111-12. Polyxena: Euripides, Hecuba 558-61. Makaria: Euripides, Heraclidae 561. In general: Cohen 1997.

20 For a persuasive defence of the authenticity of the event, see Raubitschek 1941, 906.

21 Quintilian, Inst. 2.15.9; Athenaeus 13.590F, cf. the painting by Henryk Siemiradzki, Phryne at the Poseidonia in Eleusis (sic), c. 1889. Parker 2011, 175 mistakenly charges Phryne with 'exhibitionism', as he lets Aristippus dally with Phryne on Aegina, whereas the Cynic philosopher did it with the Egyptian courtesan Lais (Athenaeus 13.588E).

22 Dionysius Hal. De imit. 5.6; Quintilian, Inst. 10.1.77, 10.5.2, cf. 1.5.61 = Corvinus fr.22 Malcovati; [Longinus] Subl. 34.3f.

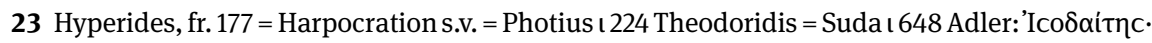

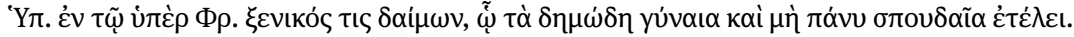


It seems that little was known about this divinity, whose earthly career surely was finished after the trial. Later authors connect him with Dionysos or Pluto, ${ }^{24}$ but it is clear that they had no independent information. ${ }^{25}$ His name, 'equal divider', seems to point to symposia, as the term occurs, albeit only once outside reports of Phryne's trial, in a symposiastic context. ${ }^{26}$ The other aspects mentioned also seem to fit the context of the symposium, as it was normal to hold a procession after a symposium (Ghiron-Bistagne 1976, 207-97; Pütz 2003). The thiasoi, 'revel bands', mentioned also fit perfectly with the context of Phryne. Robert Parker (1996, 338-39) has argued that it was a typically third-century term for 'societies of foreigners gathered round a native god'. Moreover, these societies did not contain citizens as members but mainly foreigners and slaves, who also typically honoured a foreign god. Parker does not mention Phryne in this context, but it seems that this was one of the first cases of such a thiasos, which, admittedly, had gathered around a recently invented god rather than a native divinity and, moreover, was constituted of both men and women.

There is a final aspect to Phryne's innovative rituals that also deserves to be mentioned. I have translated the Greek $\varepsilon \tau \varepsilon \dot{\lambda} \lambda \varepsilon$ in Hyperides' description of Isodaites (note 75) as 'practised mysteries'. This is, of course, not certain as it could also be translated as 'practised rituals'. Yet Greek teletê is often used for mysteries or a mysteries-like ritual (Dunbabin 2008; Schuddeboom 2009; Pirenne-Delforge 2016). Moreover, among the few fragments of Hyperides' speech we find several references to terms deriving from the Eleusinian Mysteries (Hyperides, fr. 174, 175; Pollux 8.123-24, 141, cf. O’Connell 2013). I take it, therefore, that the cult of Isodaites contained mysteries-like features, which were contrasted with those of the Eleusinian Mysteries. In fact, we know that also in another contemporaneous trial for impiety, that against the actually executed priestess Nino, remarkably similar accusations were used: 'assembling thiasoi' (Dem. 39.2, 40.9) and mocking the (surely Eleusinian) mysteries (Scholion on Dem. 19.281) (all evidence: Parker 1996, 163 n. 34; Eidinow 2016, 17-23).

Looking back, we can see, however vaguely, the picture of an enterprising woman who founded a new cult, centred on a god connected to the symposium, with Dionysiac features to the ritual but probably also mysteric aspects. Phryne

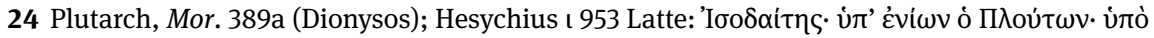

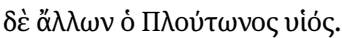

25 As rightly noted by Parker 1996, 163 n. 34. This is overlooked by Versnel 1990, 119, who wants Isodaites to be a double of Dionysos for his interpretation of Euripides' Bacchae.

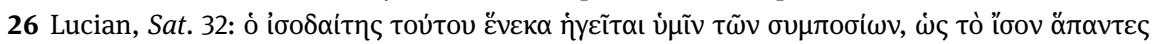

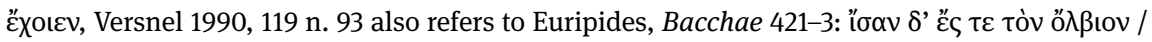

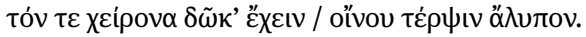


seems to have made a bricolage of various cults and rituals that attracted men and women, whereas normally Dionysiac groups at that time consisted of either men or women. We should not forget that Phryne, as a non-Athenian woman and a courtesan, had no access to the civic cults, with the exception of the Eleusinian Mysteries, and was excluded from the most prestigious Athenian women's festival, the Thesmophoria (Bremmer 2014, 168-77). Demosthenes' oration Against Neaira shows how dangerous it could be for a non-Athenian courtesan to try to behave as a citizen woman. It seems reasonable to suppose that Phryne tried to compensate for these social and religious handicaps by constructing her own cult, just as, through the centuries, women have either founded or joined new cults and religions to enable their self-realisation (Bremmer 2017, 33-41).

However, by following this course, Phryne was treading on very dangerous grounds. The Athenians saw thiasoi of non-Athenians as revel-bands that were, potentially, centres of crime and social subversion. In the case of the Boeotian Phryne, the prosecutor used this feeling and connected it to the charge of introducing a new god. As Parker $(1996,163)$ notes, 'the unlicensed god is exposed to suspicion, hostility, contempt, and the threat of actual repressive action'. Two other cases are known from the fourth century in which women were executed on the basis of comparable charges - presumably lacking advocates of the calibre of Hyperides to speak on their behalf (Trampedach 2001; Eidinow 2010). In the case of Phryne, her high visibility as a top courtesan coupled with her non-Athenian status must have made her vulnerable in any case. By infringing on the religious domain, she challenged fate. Her beauty, if not her breasts, did save her, but by all accounts it was a narrow escape.

\section{Conclusion}

What can we conclude from our cases? The religious norm in Athens was eusebeia, commonly translated as 'piety' and connected to a root *seb-, 'retreat in awe'. In the classical period, however, the element of reverence had come to the fore and was even extended to loving parents and patriotism. An important element of piety was keeping the ancestral customs. As Isocrates (7.39) observed: 'piety consists not in expensive expenditures but in changing nothing of what our ancestors have handed down' (Dover 1974, 246-54; Bruit Zaidman 2001; Beekes 2010, 2, 1315-16). Transgressions of the norm included wrongdoing during a festival, theft of sacred money, temple robbing, harm to sacred olives and, somewhat surprisingly perhaps, impiety, as we would expect the other offences to be included under impiety rather than separated out. Yet its separate mention suggests that 
impiety, asebeia, was a kind of rest category that evidently had no defined content and no fixed penalty (Parker 2005, 65, cf. Eidinow 2016, 48-62; Naiden 2016).

Moreover, an important problem that remains is the character of the law against impiety: was it procedural or substantive? Although not focusing on impiety, Edwin Harris has argued that the Athenian law was substantive (Harris 2009-2010), whereas others have taken a more procedural view (Todd 1993, $61 \mathrm{n}$. 14, 64-7) or have even argued that the law on impiety was non-specific (Macdowell 1978, 197-202; Parker 1996, 215). As far as I can see, there is no decisive evidence to decide the case, but the fact that only late sources speak of a formal law against the introduction of new gods (Josephus, Contra Apionem 2.267; Servius on Vergil, Aeneid 8.187), makes the latter position much more likely (Cohen 1991, 203-17).

In what is still one of the best studies of Socrates' trial, Moses Finley (19121986) has pointed to another problem as well. As he notes, religion was 'thoroughly enmeshed with the family and the state. Impiety was, therefore, a very loose notion'. Consequently, 'the frequency of such charges and trials in Athens depended largely on the state of public opinion at any given moment'. Finley clearly drew here on his own experience during the McCarthy years during which he had to leave the USA in order to continue with his university career (Finley 1968, 58-72 at 64, cf. Jones 2013). Indeed, Finley was one of the first to note the, what we call today, 'embedded' character of Greek religion (Parker 1986, 265, not refuted by Nongbri 2013). The Greeks had no word for our 'religion', which meant that impiety could take many different forms. This situation meant that in every impiety trial the Athenians had to decide whether the charge was persuasive or whether the charged offence constituted an acceptable exception to the norm. For example, the introduction of a new god could be perfectly acceptable at one moment in time, but not at another (so, rightly, Parker 2005, 66). Consequently, as Finley $(1968,71)$ observed regarding Socrates' trial: 'When impiety - and this is only an example - is a catch basin, no man is safe'.

It is evident that being a woman or a foreigner in this community of male citizens could be a big disadvantage. Unlike in modern Western society, it was also perfectly acceptable for a prosecutor to state that he was an enemy of the charged person or wanted to take revenge (Mitchell and Rhodes 1996; Kucharski 2012). The charge of impiety thus gave plenty of room for people to settle scores, as eusebeia was such a generous notion. These circumstances mean that, in the case of an impiety trial, the norm could always be said to have been challenged by somebody. Yet we also know that the Athenians did not condemn in every case. Indeed, they seem to have been fairly reluctant to hand out capital punishments for impiety; pollution, too, was clearly perceived as less of a threat than some prosecutors suggested (Parker 2005, 67-68). Even Socrates could probably have escaped the death penalty if he had shown more humility and less arrogance, 
as Finley (1968) persuasively argues. In the end, the norm of eusebeia allowed for acceptable exceptions, but every case was decided anew and nobody could be certain of the outcome of his or her trial. It is all too frequently forgotten that even in the case of Socrates, as Plato notes in his Apology (36a), it would only have taken some 30 people changing their view to have robbed us of the dramatic outcome of one of the most famous trials in history. We would, of course, love to know who Socrates' opponents on the jury were. Were they all conservatives? Or just opportunists? Or just normal Athenians who thought that Socrates had gone too far for once? We simply do not know. The bias of our sources prevents us from gaining a proper view of the jury's reasoning.

So what do these trials tell us about individualisation? It seems clear that in the last decades of the fifth century Athens saw a real case of de-traditionalisation, witness the contemporary agnostic, atheist and materialist discourses of philosophers and dramatists (Bremmer 2007). We should also not forget that precisely in the last quarter of the fifth century literacy made big advances in Athens. This newish technology was eagerly taken up by the Orphics, and the oldest surviving European book, the Derveni papyrus, is a great example of this development. As noted by Mirjam E. Kotwick $(2017,63)$, the book also made it possible for the various philosophical, theological, and medical experts, such as the Hippocratics, to spread their expertise.

Moreover, Socrates' claim of a special connection with the divine singled him out to an extent that apparently (see above $\S 2$ ) made other people envious. His claim surely presupposed a completely untraditional position regarding the gods and must have raised many eyebrows. In that respect, the Orphics were much more cautious, as they promised a special position only in the afterlife, even though their myths were pretty outrageous too (Waldner 2013, 225-7; Bremmer 2016). Yet these discourses did not, so far as we can see, lead to a fundamental change in religious practice. Even Socrates was not charged with breaking traditional ritual. Evidently, the power of traditional religion set a clear limit to religious individualisation in Athens. However, the religious scandals of $415 \mathrm{BC}$ can be seen as the outrageous consequence of these discourses. Yet, by all accounts, it was only a relatively small group of Athenians that dared to profane the Mysteries and to mutilate the herms.

It is virtually impossible for us to see how widely the de-traditionalising discourses were internalised by the Athenians. Our evidence is limited to the upper classes and we have no access to the personal confessions. A number of the scandalmongers of $415 \mathrm{BC}$ were executed and the survivors clearly thought it wise to keep their mouths shut. Socrates did not leave any writings, and the debate about the historical Socrates is as fruitless as that about the historical Jesus. What we can see, though, is that it was the aristocratic youths 
who followed Socrates and the sophists. They made personal choices as the traditional order and ideas clearly no longer attracted them. In this respect, we should perhaps note that the emergence of Christianity was notable for its attraction of young people (Bremmer 2017, 23-24, 387, 393, 418). One need not be a convinced follower of the rational choice theory in order to see that the young have less to lose - the hippies of the 1960s and 1970s are another fine example of this phenomenon. Yet we can also observe that after Athens' defeat we hear no more of these anti-traditional discourses. The social, political and intellectual climate had radically changed, and the influence of the sophists had been discredited by their aristocratic followers. Evidently, individualisation is not a linear trend but can, even if perhaps temporarily, be stopped by unfavourable historical circumstances.

Phryne is a different case. The fourth century BC showcases a number of women who tried to improve their position by marrying husbands to whom they were not really entitled, the most famous being, perhaps, Neaira (Glazebrook 2005; Bakewell 2008). If we are looking for female agency, there is plenty to find in the forensic speeches (Eidinow 2016, 312-25). Yet the case of Phryne is different as it is more ambitious. Here we have an outsider woman who tries to make the most of her position, perhaps even trying to leave the profession of courtesan behind her and to improve her social status by the invention of a new cult. Once again, her motivation is unclear and can no longer be recovered. Given the limitations in religious life for non-free women - being a courtesan prevented Phryne from, for example, participating in the prestigious Thesmophoria - it is perhaps not wholly unsurprising that her ambition was to found a new, enduring cult. If we want to see an individualising woman, there could be no better example than Phryne. Unfortunately, our material rarely allows us to gain a good picture of similar women. Still, I hope to have shown that classical Greece should not be neglected in discussions of religious individualisation.

\section{References}

Bakewell, Geoffrey. 2008. 'Forbidding Marriage: Neaira 16 and Metic Spouses at Athens', Classical Journal 104. 97-109.

Bartolini, Gianfranco. 1977. Iperide. Padua: Antenore.

Baumeister, Theodor. 2009. Martyrium, Hagiographie und Heiligenverehrung im christlichen Altertum. Freiburg: Herder.

Beekes, Robert. 2010. Etymological Dictionary of Greek. 2 vols. Leiden: Brill.

Benz, Ernst. 1950/51. 'Christus und Socrates in der alten Kirche', Zeitschrift für die neutestamentliche Wissenschaft 43. 195-224.

Boegehold, Alan L. 1999. When a Gesture was Expected. Princeton: Princeton University Press. 
Brandt, Jared. 2017. 'Socrates, the Daimonion, and Rational Trust: A Perspectival Account', Apeiron 50. 416-34.

Bremmer, Jan N. 2007. 'Atheism in Antiquity'. In The Cambridge Companion to Atheism, ed. Michael Martin, Cambridge: Cambridge University Press. 11-26.

Bremmer, Jan N. 2008. Greek Religion and Culture, the Bible and the Ancient Near East. Leiden: Brill.

Bremmer, Jan N. 2010. 'Manteis, Magic, Mysteries and Mythography: Messy Margins of Polis Religion?', Kernos 23.13-35.

Bremmer, Jan N. 2013. 'The Agency of Greek and Roman Statues: from Homer to Constantine', Opuscula 6. 7-21.

Bremmer, Jan N. 2014. Initiation into the Mysteries of the Ancient World. Berlin/Boston: de Gruyter.

Bremmer, Jan N. 2016. 'The Construction of an Individual Eschatology: the Case of the Orphic Gold Leaves'. In Burial Rituals, Ideas of Afterlife, and the Individual in the Hellenistic World and the Roman Empire, eds. Katharina Waldner, Richard L. Gordon and Wolfgang Spickermann, Stuttgart: Steiner. 31-52.

Bremmer, Jan N. 2017. Maidens, Magic and Martyrs in Early Christianity. Tübingen: Mohr Siebeck. Bremmer, Jan N. 2019. 'Ritual and its Transgressions in Ancient Greece'. In A Historical Approach to Casuistry. Norms and Exceptions in a Comparative Perspective, eds. Carlo Ginzburg and Lucio Biasiori, London: Bloomsbury, 47-64.

Bruit Zaidman, Louise. 2001. Le Commerce des dieux. Paris: Découverte.

Cavallini, Eleonora. 2008. 'Phryne from Knidian Venus to Movie Star'. In Hellas on Screen, ed. Irene Berti, Stuttgart: Steiner. 203-18.

Cohen, Beth. 1997. 'Divesting the Female Breast of Clothes in Classical Sculpture'. In Naked Truths. Women, Sexuality, and Gender in Classical Art and Archaeology, eds. Ann 0. Kolosklostrow and Claire L. Lyons, London/New York: Routledge. 43-96.

Cohen, David. 1991. Law, Sexuality and Society: The Enforcement of Morals in Classical Athens. Cambridge: Cambridge University Press.

Cooper, Craig. 1995. 'Hyperides and the Trial of Phryne', Phoenix 49. 303-18.

Corpataux, Jean-François. 2009. 'Phryné, Vénus et Galatée dans l'atelier de Jean-Léon Gérôme', Artibus et historiae 59. 145-58.

Danzig, Gabriel. 2014. 'The Use and Abuse of Critias: Conflicting Portraits in Plato and Xenophon', Classical Quarterly 64. 507-24.

Dassmann, Ernst. 1993. 'Christus und Sokrates', Jahrbuch für Antike und Christentum 36. 33-45. Döring, Klaus. 1979. Exemplum Socratis. Wiesbaden: Steiner.

Dover, Kenneth J. 1974. Greek Popular Morality in the Time of Plato and Aristotle. Oxford: Blackwell.

Dunbabin, Katherine. 2008. 'Domestic Dionysus? Telete in Mosaics from Zeugma and the Late Roman Near East', Journal of Roman Archaeology 21. 193-224.

Dunbar, Nan. 1995. Aristophanes Birds. Oxford: Oxford University Press.

Eidinow, Esther. 2010. 'Patterns of Persecution: 'Witchcraft' Trials in Classical Athens', Past and Present 208. 9-35.

Eidinow, Esther. 2016. Envy, Poison, \& Death. Oxford: Oxford University Press. Filonik, Jakub. 2013. 'Athenian Impiety Trials: A Reappraisal', Dike 16. 11-96.

Filonik, Jakub. 2016. 'Impiety Avenged: Rewriting Athenian History'. In Splendide Mendax: Rethinking Fakes and Forgeries in Classical, Late Antique, and Early Christian Literature, eds. Edmund P. Cueva and Javier Martínez, Groningen: Barkhuis. 25-40. 
Finley, Moses I. 1968. Aspects of Antiquity. London: Chatto and Windus.

Fredal, James. 2008. 'Why Shouldn't the Sophists Charge Fees?', Rhetoric Society Quarterly 38. $148-70$.

Furley, William D. 1996. Andocides and the Herms: a Study of Crisis in Fifth-Century Athenian Religion. London: Institute of Classical Studies.

Fusillo, Marco. 1992. 'Was ist eine romanhafte Tragödie? Überlegungen zu Euripides' Experimentalismus', Poetica 24. 270-99.

Gagné, Renaud. 2013. Ancestral Fault in Ancient Greece. Cambridge: Cambridge University Press.

Geffcken, Johannes. 1908. Sokrates und das alte Christentum. Heidelberg: Winter.

Graf, Fritz. 2000. 'Der Mysterienprozess'. In Grosse Prozesse im antiken Athen, eds. Leonhard Burckhardt and Jürgen von Ungern-Sternberg, Munich: Beck. 114-27.

Gherchanoc, Françoise. 2012. 'La beauté dévoilée de Phryné. De l'art d'exhiber ses seins', Metis NS 10. 199-223.

Ghiron-Bistagne, Paulette. 1976. Recherches sur les acteurs dans la Grèce antique. Paris: Les Belles Lettres.

Glazebrook, Allison. 2005. 'The Making of a Prostitute: Apollodoros's Portrait of Neaera', Arethusa 38. 161-87.

Haake, Matthias. 2016. 'Asebie als Argument. Zur religiösen Fundierung politischer Prozesse im klassischen und hellenistischen Griechenland: das Beispiel der athenischen Philosophenprozesse'. In Rechtliche Verfahren und religiöse Sanktionierung in der griechisch-römischen Antike, eds. Daniela Bonanno, Peter Funke and Matthias Haake, Stuttgart: Steiner. 207-22.

Hansen, Mogens H. 1995. The Trial of Sokrates - from the Athenian Point of View. Copenhagen: Tusculum.

Harder, Annette, Remco F. Regtuit and Gerry C. Wakker (eds.). 2002. Noch einmal zu...Kleine Schriften von Stefan Radt zu seinen 75. Geburtstag. Leiden: Brill.

Harnack, Adolf. $1906^{2}$. Reden und Aufsätze I. Giessen: Töpelmann. 17-49.

Harris, Edward. 2009-2010. 'What are the Laws of Athens about? Substance and Procedure in Athenian Statutes', Dike 12-13.5-67.

Hölscher, Fernande. 2017. Die Macht der Gottheit im Bild. Heidelbrg: Verlag Antike.

Hornblower, Simon. 2008. A Commentary on Thucydides, Vol. III. Oxford: Oxford University Press.

Hornblower, Simon. 2010. Thucydidean Themes. Oxford: Oxford University Press.

Horst, Pieter Willem van der. 2006. Jews and Christians in Their Graeco-Roman Context. Tübingen: Mohr Siebeck.

Hunt, Lynn. 2014. Writing History in the Global Era. New York/London: W.W. Norton \& Company. Jones, Thai. 2013. 'Un-Athenian Affairs: I.F. Stone, M.I. Finley, and the Trial of Socrates'. In Moses Finley and Politics, ed. William V. Harris, Leiden: Brill. 123-41.

Kepetzis, Ekaterini. 2011. 'Transformationen der Phryne. Jean-Léon Gérômes antikische Gattungshybriden zwischen Missverständnis und Provokation'. In Imagination und Evidenz. Transformationen der Antike im ästhetischen Historismus, ed. Ernst Osterkamp and Thorsten Valk, Berlin/Boston: De Gruyter. 291-312.

Kindt, Julia. 2012. Rethinking Greek Religion. Cambridge: Cambridge University Pres.

Kindt, Julia. 2015. 'Personal Religion: A Productive Category for the Study of Ancient Greek Religion?', Journal of Hellenic Studies 135. 35-50.

Klöckner, Anja. In preparation. 'Facing the Sacred. Emotions in Images of Cult and Ritual'. 
Kotwick, Mirjam E. 2017. Der Papyrus von Derveni. Berlin/Boston: de Gruyter.

Kucharski, Janek. 2012. 'Vindictive Prosecution in Classical Athens: On Some Recent Theories', Greek, Roman, and Byzantine Studies 52.167-97.

Laks, André and Rossella Saetta Cottone (eds.). 2013. Comédie et philosophie. Socrate et les "Présocratiques" dans les Nuées d'Aristophane. Paris: Éd. Rue d'Ulm.

Lännstrom, Anna. 2012. 'Trusting the Divine Voice: Socrates and His Daimonion', Apeiron 45. 32-49.

Lapaire, Claude. 2010. James Pradier (1790-1852) et la sculpture française de la génération romantique. Catalogue raisonné. Zürich/Lausanne/Milan: 5 Continents Éditions.

Lefkowitz, Mary L. 1987. 'Was Euripides an Atheist?', Studi Italiani di Filologia Classica III.5. 149-66.

Lefkowitz, Mary L. 1989. “'Impiety” and “Atheism” in Euripides Dramas', Classical Quarterly 39. 70-82.

Lenfant, Dominique. 2015. 'La chute d'Anytos et la vengeance de Socrate: à propos d'une légende tenace', Rationes rerum 5. 117-28.

Macdowell, Douglas. 1978. The Law in Classical Athens. London: Duckworth.

Martin, Gunther. 2007. Divine Talk. Religious Argumentation in Demosthenes. Oxford: Oxford University Press.

McGlew, James F. 1999. 'Politics on the Margins: The Athenian "Hetaireiai” in 415 B.C.', Historia 48. 1-22.

Millett, Paul. 2005. 'The Trial of Socrates Revisited', European Review of History 12. 23-62.

Mitchell, Lynette G. and Peter J. Rhodes. 1996. 'Friends and Enemies in Athenian Politics', Greece \& Rome 43. 11-30.

Momigliano, Arnaldo. 1987. Ottavo contributo alla storia degli studi classice del mondo antico. Rome: Edizioni di storia e letteratura.

Morales, Helen. 2011. 'Fantasising Phryne: The Psychology and Ethics of Ekphrasis', Cambridge Classical Journal 57. 71-104.

Murray, Oswyn. 1990. 'The Affair of the Mysteries: Democracy and the Drinking Group'. In Sympotica, ed. Oswyn Murray, Oxford: Oxford University Press. 149-61.

Naiden, Fred S. 2006. Ancient Supplication. Oxford: Oxford University Press.

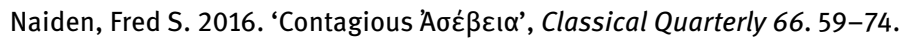

Nongbri, Brent. 2013. Before Religion. New Haven/London: Yale University Press.

Ober, Joshua. 2011. 'Socrates and Democratic Athens'. In The Cambridge Companion to Socrates, ed. Donald R. Morrison, Cambridge: Cambridge University Press. 138-78.

O'Connell, Peter. 2013. 'Hyperides and Epopteia: A New Fragment of the Defense of Phryne', Greek, Roman, and Byzantine Studies 53. 90-116.

Osborne, Robin. 2010. Athens and Athenian Democracy. Cambridge: Cambridge University Press. Parker, Robert. 1986. 'Greek Religion'. In The Oxford History of the Classical World, eds. John Boardman, Jasper Griffin and Oswyn Murray, Oxford: Oxford University Press. 254-74.

Parker, Robert. 1996. Athenian Religion. Oxford: Oxford University Press.

Parker, Robert. 2005. 'Law and Religion'. In The Cambridge Companion to Ancient Greek Law, eds. Michael Gagarin and David Cohen, Cambridge: Cambridge University Press. 61-81.

Parker, Robert. 2011. On Greek Religion. Ithaca/London: Cornell University Press.

Pedrina, Marta. 2006. 'Tendre les mains, supplier du regard: Télèphe et Dryas'. In L'expression des corps. Gestes, attitudes, regards dans l'iconographie antique, eds. Lydie Bodiou, Dominique Frère and Véronique Mehl, Rennes: Presses universitaires de Rennes. 299-310. 
Pfättisch, Joannes Maria 1908. 'Christus und Sokrates bei Justin', Theologische Quartalschrift 90.503-23.

Pirenne-Delforge, Vinciane. 2009. 'Teletê peut-elle être déesse? Note épigraphique (SEG 50, 168)', Mètis 14. 35-48.

Pütz, Babette. 2003. The Symposium and Komos in Aristophanes. Beiträge zum antiken Drama und seiner Rezeption. Stuttgart/Weimar: Metzler.

Raubitschek, Antony. 1941. 'Phryne'. In Paulys Realencyclopädie der classischen Altertumswissenschaft 20.1. 893-907.

Riedweg, Christoph. 1990a. 'A Euripidean Fragment', Classical Quarterly 40. 124-36.

Riedweg, Christoph. 1990b. 'The “Atheistic” Fragment from Euripides' Bellerophontes (286 N²)', Illinois Classical Studies 15. 39-53.

Rubel, Alexander. 2000. Stadt in Angst. Religion und Politik in Athen während des Peloponnesischen Krieges. Darmstadt: Wissenschaftliche Buchgesellschaft.

Rubel, Alexander. 2014. Fear and Loathing in Ancient Athens. Abingdon/New York: Routledge.

Rüpke, Jörg. 2011. 'Lived Ancient Religion: Questioning “Cults” and “Polis Religion”', Mythos 5. 191-204.

Rüpke, Jörg. 2015. 'Religious Agency, Identity, and Communication: Reflections on History and Theory of Religion', Religion 45. 344-66.

Rüpke, Jörg. 2016. 'Ein neuer Religionsbegriff für die Analyse antiker Religion unter der Perspektive von Weltbeziehungen', Keryx 4. 21-35.

Ryan, Judith. 1993. 'More Seductive than Phryne: Baudelaire, Gérôme, Rilke, and the Problem of Autonomous Art', Proceedings of the Modern Language Association 108. 1128-41.

Sato, Noburu. 2013. 'Religious and Political Trial: Another Aspect of Anytus' Prosecution against Socrates', KODAl: Journal of Ancient History 15 (2005-2008). 25-40.

Schrödl, Barbara. 2013. 'Phryne Paves the Way for the Wirtschaftswunder: Visions of Guilt and "Purity" Fed by Ancient Greece, Christian Narrative, and Contemporary History". In Ancient Worlds in Film and Television: Gender and Politics, eds. Almut-Barbara Renger and Jon Solomon, Leiden: Brill. 299-310.

Schuddeboom, Fedde. 2009. Greek Religious Terminology - Telete \& Orgia: A Revised and Supplemented English Edition of the Studies by Zijderveld and Van der Burg. Leiden: Brill.

Thomas, Keith. $2010^{2}$. The Ends of Life. Oxford: Oxford University Press.

Todd, Stephen. 1993. The Shape of Athenian Law. Oxford: Oxford University Press.

Todd, Stephen. 2004. 'Revisiting the Herms and the Mysteries'. In Law, Rhetoric, and Comedy in Classical Athens: Essays in Honour of Douglas M. MacDowell, eds. Douglas Cairns and Ronald A. Knox, Cardiff: Wales University Press. 87-102.

Todd, Stephen. 2007. A Commentary on Lysias, Speeches 1-11. Oxford: Oxford University Press. Trampedach, Kai. 2001. 'Gefährliche Frauen. Zu athenischen Asebie-Prozessen im 4. Jh. v. Chr.'. In Konstruktionen von Wirklichkeit. Bilder im Griechenland des 5. und 4. Jahrhunderts v. Chr., eds. Ralf von den Hoff and Stefan Schmidt, Stuttgart: Steiner. 137-55.

Versnel, Hendrik S. 1990. Inconsistencies in Greek and Roman religion. 1. Ter Unus Isis, Dionysos, Hermes; Three Studies in Henotheism. Leiden: Brill.

Versnel, Hendrik S. 2011. Coping with the Gods: Wayward Reading in Greek Theology. Leiden: Brill.

Vouilloux, Bernard. 2002. Le tableau vivant. Phryné, l'orateur et le peintre. Paris: Flammarion.

Waldner, Katharina. 2013. 'Individual Dimensions of Ancient Mystery Cults: Religious Practice and Philosophical Discourse'. In The Individual in the Religions of the Ancient Mediterranean, ed. Jörg Rüpke, Oxford: Oxford University Press. 215-42. 
Whitmarsh, Tim. 2015. Battling the Gods. New York: Alfred A. Knopf.

Wittenburg, Andreas. 2007. 'Nu classique et voyeurisme. Femmes et hommes, Antiquité et Orient dans la peinture du xixe siècle'. In Problèmes du genre en Grèce ancienne, eds. Violaine Sebillotte Cuchet and Nathalie Ernoult, Paris: Sorbonne. 197-214.

Yunis, Harvey. 1988. A New Creed: Fundamental Religious Beliefs in the Athenian Polis and Euripidean Drama. Göttingen: Vandenhoeck \& Ruprecht. 